\title{
CROSS-MAPPING THE GOTHIC
}

Daniel Serravalle de Sá

Universidade Federal de Santa Catarina

Anelise Reich Corseuil

Universidade Federal de Santa Catarina

This special issue of Ilha do Desterro is dedicated to crossmapping contemporary perspectives on the Gothic as it manifests itself in different media around the world. The volume gathers academic essays and reviews by scholars from different institutions in Brazil and elsewhere. The texts offered here analyse Gothic cultural productions from different perspectives, exploring the growing field of Gothic studies worldwide in its many forms and approaches and constitute what we would like to call a cartography of the Gothic, as it crosses national and disciplinary borders in a variety of ways - a fertile ground for exploring local as well as wide-reaching interests and anxieties within, without, and across conventional geographic and generic borders.

Gothic studies, the academic field that explores the Gothic text, has developed substantially over the last hundred years or so

\begin{tabular}{|l|l|l|l|l|}
\hline Ilha do Desterro & Florianópolis & $n^{\circ} 62$ & p. 011-021 & jan/jun 2012 \\
\hline
\end{tabular}


to become, more recently, an international phenomenon. Presentday Gothic criticism can look back on a body of critical works that progressed from initial literary curiosity to distinctive theoretical framework. At present Gothic studies has become a fully-fledged area of study with a growing critical bibliography as well as widespread popularity manifest in the proliferation of undergraduate and postgraduate courses, scholarly associations, and journals. But, for a broader view, Gothic studies also encompass non-academic areas including discussion forums, thematic websites dedicated to the subject, networks organisations and underground publications in various media, not to mention the lively production of Gothic material in music, video, fashion, even body art.

Gothic criticism can be said to begin in the early twentieth century with the publication of seminal works such as Dorothy Scarborough's The Supernatural in Modern English Fiction (1917), Edith Birkhead's The Tale of Terror (1921), Eino Railo's The Haunted Castle (1927), Mario Praz's The Romantic Agony (1933), Montague Summers's The Gothic Quest (1938), Devendra Varma's The Gothic Flame (1957), among other influential studies. These critical works have helped to retrieve fictional Gothic texts from a position of marginality to a place closer to the literary canon. In the late 1960s scholars working in the field of Romantic studies played an important role in establishing Gothic criticism as a distinctive field of knowledge. Robert Hume's and Robert Platzner's well-known debate on 'Gothic versus Romantic' (1969) is perhaps the most representative exchange of this period, which contributed to raise further interest in Gothic fiction resulting in a number of critical studies in the area.

More recently a number of other critical and theoretical developments in literary theory, including feminist, psychoanalytic, 
poststructuralist, new historicist, and cultural approaches, have set in motion the process of internationalisation that can be observed at least since the 1980s. Eve K. Sedgwick's The Coherence of Gothic Conventions (1980), David Punter's The Literature of Terror (1980), Rosemary Jackson's Fantasy: The Literature of Subversion (1981), Victor Sage's Horror Fiction in the Protestant Tradition (1988), along with many other important critical works published in the 1990s and 2000s, have consolidated Gothic studies as a field worthy of academic discussion and intellectual debate.

From a historical perspective the literary Gothic, with its stories of supernatural terror, horror, mystery and melodrama, is associated with the rise of the novel genre in the mid-eighteenth century and with the development of the short story in the early nineteenth century; it was once considered exclusively an Anglo-American genre. More recently critics worldwide have begun to locate their own specific cultural traditions of supernatural terror, horror, mystery, and melodrama. As a result, the definition has been broadened, there has been a growing sense of a less circumscribed Gothic, and it is increasingly being recognised as an element in a larger set of cultural traditions.

The commercial success and cult popularity of contemporary productions that employ the Gothic as an element of their compositional structure have helped to put the subject on the world map. Books, graphic novels, films, TV series, videogames and other types of creative texts, including a whole aesthetics associated with fashion, music, behaviour and underground culture, that make reference to the Gothic have created an overall notion of the nature of the Gothic, and also stimulated extensive academic research. Nonetheless, in spite of its recent global popularisation, the Gothic remains a controversial subject and is sometimes poorly understood outside the specialised field. Although "the Gothic" is a well- 
established critical category in English studies, to this day there is no consensus on a precise definition of the term and no singular definition of the Gothic is available.

A brief survey confirms that the meaning of the Gothic is fluid: David Punter notes that "the notion of what constitutes Gothic writing is a contested site" (viii). Lenora Ledwon thinks that "part of the difficulty lies in the fact that, rather than speaking of one monolithic category of 'Gothic', it is more appropriate to recognise there are many Gothics" (261). Glennis Byron states that the Gothic is "a set of irreconcilable and contradictory values both in aesthetic and political terms" (4). Fred Botting argues that "the search for the Gothic [...] is a vain critical endeavour" (1). At this time the closest one can come to a definition may be to say that the Gothic is a flexible mode which fits several different cultural forms and ideological dynamics that come from distinct directions. Ambivalence, indeterminacy and multiplicity are key elements of the Gothic, since neither Gothic literature and film, nor the studies of them, operate under a single paradigm. Both creative and critical works expand the stylistic and ideological parameters of the form to produce an array of "Gothics". Within this theoretical framework, the essays in this volume problematise traditional historical, national, and linguistic connotations associated with the Gothic, identifying new directions and cultural contexts of production.

The essays in this edition are divided in two sections organised around the concept of maps or cartographies of the Gothic. The first section, entitled The Gothic in Europe, contemplates the Gothic production originating in England, Ireland, Holland, Germany and Italy, with essays that analyse the work of writers such as Matthew Gregory Lewis, Joseph Conrad, Jane Austen, Charlotte Riddell, Wilkie Collins, Jacob van Lennep, Ludwig Tieck, and of filmmakers 
such as Mario Bava and Dario Argento. The second section, entitled The Gothic in New Landscapes, ranges from the USA to Mexico and to Brazil, presenting essays that bring contemporary perspectives on the works of writers such as Charles Brockden Brown, José de Alencar, Cornélio Penna, Álvares de Azevedo, and filmmakers such as Tod Browning, Karl Freund, Victor Halper, Rodrigo Pla and Walter Hugo Khouri.

The first section, The Gothic in Europe, opens with Abigail Lee Six's 'The Monk (1796): a Hispanist's Reading', which suggests a relation between Spanish honour plays of the seventeenth century and the Gothic, to which they may be seen as precursors. Lee Six argues that the Spanish concept of "honour plays" sheds light upon numerous Gothic characteristics, including the centrality of sexual secrets and imprisoned women, as well as its predilection for gore. From an analysis of The Monk, with particular emphasis on the characterisation of priest-villain Ambrosio, the author considers Lewis's opportunities to access a Spanish corpus.

Our second and third essays contemplate relations between England and what is "other" to it. In 'Heart of Darkness and the Fear of going Native', Anna Reid examines Conrad's masterpiece as a representative of the "Imperial Gothic", highlighting late-Victorian fears concerning otherness, degeneration, and dehumanization as a backlash against the European Imperial mission. She analyses the pauses and silences in Marlow's monologue, and the detached voices that echo through the jungle above gunfire and dying groans, as Gothic anxieties, instances of the unspeakable, the abject, and the horror of the colonial enterprise. In 'Jane Austen e a recodificação paródica do gótico em Northanger Abbey', Genilda Azerêdo discusses the construction and effects of parodic discourse in Jane Austen's novel Northanger Abbey (1818). Given that parody is considered 
a meaningful form for the discussion of intertextuality, the author argues that Jane Austen actively and creatively re-codifies some aspects of the eighteenth-century Gothic tradition. The author identifies a number of parodic elements in the novel and discusses the effects of parody within a larger context of metafiction.

Ilse Bussing's essay 'Sequestered Spaces and Defective Doors in tales by Collins and Riddell' argues that architecture is a key Gothic element in Wilkie Collins's The Dead Secret (1857) and Charlotte Riddell's short story "The Open Door" (1882). For the author, architecture engenders and shapes haunted space within Gothic texts, generally framing issues of excess and transgression. Moreover, the spatial and theoretical considerations generated by the medieval castle and the Victorian house suggest that these sites were not mere settings for supernatural activity but often functioned as protagonists. Bussing focuses particularly on doors as the architectural feature whose symbolic charge best expresses concerns about privacy and concealment, spatial anxiety and infiltration in Gothic texts.

The relations between the Gothic and Dutch literature are presented in Agnes Andeweg's essay 'How the Gothic Reared its Head in Dutch Literature. The author offers a panorama of the Gothic in Dutch literature, focusing particularly on the 1980s as arguably the high point of Dutch Gothic fiction. Andeweg discusses the reasons for the absence of a more significant Dutch Gothic tradition before the 1980s and then examines six novels from the decade analysing the socio-cultural role of the Gothic form in these novels, particularly how it works as a way of expressing ambivalence about reformulations in the domain of gender and sexuality.

In the essay 'Ludwig Tieck: meandros góticos', Karin Volobuef highlights literary images and themes that likely connect the 
production of German novelist Ludvig Tieck to the work of eighteenth-century British Gothic novelists, especially Matthew G. Lewis. A leading member of the Jena Romantics group, Tieck is an influential writer of the first phase of German Romanticism, and his work depicts characters that not only face external perils but also have to fight self-doubt, "angst" and other triggers of internal crisis. The author departs from the broader critical perspective of the Fantastic genre to focus on the more sinister and grotesque (and arguably Gothic) side of Tieck's stories.

Keith H. Brown's article 'Gothic/Giallo/Genre: Hybrid Images in Italian Horror Cinema, 1956-82' demonstrates the similarities between filmic elements in the works of Italian filmmaker's Mario Bava and Dario Argento which transcend the traditional division between classical and modern, Gothic and Giallo. Through an analysis of both the manipulation of light-shadow and the concept of space in cinema, the author develops his arguments with particular reference to Deleuze's concepts of the classical 'movement-image' and modern 'time-image', contending that Bava and Argento's treatments of space and time encompass elements that can unite cinemas from different periods.

Our second section, The Gothic in New Landscapes, opens with Renata R. Mautner Wasserman's 'Gothic Roots: Brockden Brown's Wieland, American Identity, and American Literature'. She analyses the Gothic elements in Charles Brockden Brown's Wieland (1798), a founding novel of the recently independent United States of America. Wasserman argues that the European Gothic novel's treatment of issues such as class, gender, religion, and national identity proved to be an adaptable and useful literary form for exploring topics of nation-building and national sovereignty, which were of great importance for the American novel of the period. 
In the article 'Exotic Primitivism of Death in Classical Hollywood Living Dead Films', Outi Hakola analyses the cross-cultural limits of 1930s Hollywood classic horror films. She discusses trans-cultural characteristics appearing particularly in the 'living dead' film genre, which feature Eastern European vampires, Egyptian mummies, Haitian zombies, among other lifeless, foreign monsters. Hakola argues these living dead characters symbolise the tension between traditional or primitive views of death or reactions to death, and the western and modern understandings of mortality where dying often gets intruded by science, medical practices and authorities.

Bernice M. Murphy's article 'How Will I Explain Why We Live Behind a Wall? La Zona (2007) as Suburban Gothic Narrative' discusses Gothic manifestations, in the form of tropes and themes, in director Rodrigo Pla's dramatisation of Mexican middle-class fears about family and community safety, communal solidarity and acts of mob violence, which can be seen as a political critique of contemporary Mexican culture and society. What Murphy calls the Suburban Gothic emerges as a means of expressing regional economic and political anxieties about the relationship between the privileged and the disenfranchised, specifically Mexican anxieties about the liberties afforded to the wealthy and the ramifications of police corruption and political cronyism.

Moving from Mexico to Brazil, we have Sandra G. T. Vasconcelos's essay 'Sentidos do demoníaco em José de Alencar', which explores appropriations of the Gothic form in Brazilian novels $O$ Gaúcho, Til and $O$ Tronco do Ipê, by nineteenth-century writer José de Alencar. She argues that the novelist borrowed and acclimatised some Gothic conventions, more particularly those that were useful for the representation of Brazilian rural life as a violent and excessive experience. The article enquires into the meanings of 
these appropriations, suggesting they are linked to the process of constructing a sense of a recognisably Brazilian nation.

In the article 'Daughters of Fire: Walter Hugo Khouri's Female Gothic', Daniel Serravalle de Sá contemplates the transnational characteristics of the Gothic using the film As Filhas do Fogo (1978) as an example of the relation between gender and a more recent take on the issue of constructing sense of Brazilian history. In this film, the main female characters find themselves trapped in a Gothic situation in which the luxuriant Brazilian forest overwhelms a tropical manor, thereby returning it to nature. Starting from a discussion of the haunted house as a time-honoured Gothic feature, the author argues for the social significance of this development of the trope in the Brazilian context.

Josalba Fabiana dos Santos's essay 'O castelo (quase) vazio: marcas do gótico em Fronteira, de Cornélio Penna' argues that the Gothic features in Cornélio Penna's novel Fronteira (1935) are representative of the relation of admiration and repulse that Brazilian literature maintained with the European tradition at the time. The author focuses on the vicissitudes of young Maria Santa, a character who lives under the constant threat of physical and moral damage. Set in the early days of the Brazilian Republic, it shows the secluded town of Itabira as it becomes the setting for a narrative of rape and murder. An old colonial manor, sinister family portraits, and an insect collection framed in glass are some potentially Gothic elements that suggest Cornélio Penna's rewriting of Gothic forms within his own social dimension and time.

Julio França's and Luciano Cabral da Silva's 'A Preface to a Theory of Art-Fear in Brazilian Literature' seeks to identify basic characteristics of Brazilian fictional horror informed by Noël Carroll's concept of "fear literature"- fictional narratives that produce 
fear by artistic means. The authors argue that a number of Brazilian literary texts could be read in such key and that the lack of a national horror tradition in Brazil is due to critical favouritism for narratives that represent social problems in a 'realistic' way.

Finally the review section brings Natasha Rebry's considerations about John Sears's Stephen King's Gothic (University of Wales Press, 2011) and Marcia Tiemy Morita Kawamoto's evaluation of Maria Beville's Gothic-Postmodernism, Voicing the Terrors of Postmodernity (Rodopi, 2009).

Taken as a whole, the varied collection of texts here shows that the Gothic, starting with Horace Walpole's protean The Castle of Otranto, far from being a marginal cultural strand, constitutes an important critique of the last two hundred and fifty years of culture or so, remaining as a crucial element in its construction and even, at the same time, an essential aide in bringing to awareness something like a cultural subconscious.

\section{References}

Birkhead, Edith. The Tale of Terror: a Study of the Gothic Romance. New York: Russell and Russell, [1921] 1963. Print.

Botting, Fred (ed). The Gothic. London: D.S. Brewer, 2001. Print.

Byron, Glennis. 'Gothic in the 1890s', in D. Punter (ed) A Companion to the Gothic. Oxford: Blackwell, 2000.132-141. Print.

Horner, Avril (ed). European Gothic: a Spirited Exchange 1760-1960. Manchester: Manchester University Press, 2002. Print.

Hume, Robert D. "Gothic versus Romantic: a Revaluation of the Gothic Novel,” PMLA 84, 1969. 282-90. Print.

Jackson, Rosemary. Fantasy: The Literature of Subversion. London: Methuen, 1981. Print. 
Kilgour, Maggie. The Rise of the Gothic Novel. London: Methuen, 1995. Print.

Ledwon, Lenora. 'Twin Peaks and the Television Gothic', Literature/Film Quarterly, 21(4), 1993. 217-220. Print.

Platzner, Robert L. and Robert D. Hume."'Gothic versus Romantic': a Rejoinder," PMLA 86, 1971. 266-74. Print.

Praz, Mario. The Romantic Agony. Translated by Angus Davidson. Oxford: Oxford University Press, [1933] 1970. Print.

Punter, David. The Literature of Terror: a History of Gothic Fictions from 1765 to the Present Day. London: Longman, 1980. Print.

Railo, Eino. The Haunted Castle: A Study of the Elements of English Romanticism. New York: Humanities Press [1927] 1964. Print.

Sage, Victor. Horror Fiction in the Protestant Tradition. Basingstoke: Macmillan, 1988. Print.

Scarborough, Dorothy. The Supernatural in Modern English Fiction. New York: Putnam, 1917. Print.

Sedgwick, Eve K. The Coherence of Gothic Conventions. London: Methuen, [1980] 1986. Print.

Summers, Montague. The Gothic Quest: a History of the Gothic Novel. New York: Russell and Russell, [1938] 1964. Print.

Townshend, Dale. The Orders of Gothic: Foucault, Lacan, and the Subject of Gothic Writing 1764-1820. New York: AMS Press, 2007. Print.

Varma, Devendra P. The Gothic Flame: Being a History of the Gothic Novel in England: Its Origins, Efflorescence, Disintegration, and Residuary Influence. New York: Russell and Russell, [1957] 1966. Print. 
